УДК 005.95:005.336.2

DOI: https://doi.org/10.37320/2415-3583/14.8

Корольов Д.С.

аспірант кафедри публічного управління, менеджменту та маркетингу, Східноукраїнський наџіональний університет імені Володимира Даля

\title{
КОМПЕТЕНЦЙНА СИНЕРГІЯ ЯК КРИТЕРІЙ ЕФЕКТИВНОСТІ ФУНКЦІОНУВАННЯ УПРАВЛІНСЬКИХ КОМАНД
}

\begin{abstract}
Обтрунтовано, щзо цеентральною проблемою оцінювання результативності управлінської команди є забезпечення ії відповідності певним критеріям ефективності функиіонування. На підставі аналізу підходів до визначення критеріїв ефективності управлінської команди доведено необхідність забезпечення позитивного ефекту від взаємодії ї̈ учасників у вигляді структурної, функціональної та адміністративної синергії. Показано, щчо джерелами синергетичного ефекту виступатиме формування оптимальних організаційної, рольової та комунікативної структур із погляду їх відповідності завданням управлінськой команди. Сумарний синергетичний ефект визначено як компетениійну синергію та обтрунтовано доиільність його ототожнення з комплексним критерієм ефективності функиіонування управлінської команди.
\end{abstract}

Ключові слова: компетентнісний підхід, управлінська команда, структура, критерій, синергетичний ефект, компетенційна синергія.

Постановка проблеми. В епоху постіндустріальної економіки конкуренція перейшла межі суперництва у сфері ефективного розпорядження матеріальними ресурсами та перебуває у площині конкуренції управлінських структур. Визначальну роль за таких умов відіграє створення управлінських команд, які здатні забезпечити позитивний ефект від налагодженої співпраці менеджерів різних рівнів ієрархії та різних функціональних напрямів. Залежність результативності командної роботи від різноманітності та рівня розвитку компетенцій ії учасників зумовлює необхідність дослідження критеріїв ефективності функціонування команди працівників 3 погляду компетентнісного підходу до управління персоналом.

Аналіз останніх досліджень і публікацій. Спектр критеріїв ефективності функціонування управлінської команди є дуже різноманітним та варіюється згідно 3 підходами різних науковців. Так, на думку В.О. Москаленко, ефективність команди управлінців може бути оцінена $з$ погляду таких критеріїв, як [1, с. 85]: чітке розуміння цілі та спрямованість на кінцевий результат; чіткий розподіл функцій та відповідальності; наявність плану розвитку команди; взаєморозуміння і безконфліктність; активність участі у вирішенні проблем; командна синергія.

Згідно з підходом К.С. Калинець, до характеристик конкурентоспроможної (тобто ефективної) управлінської команди належать [2]: особистісна (індивідуальна) конкурентноздатність кожного учасника команди; сприйняття учасниками команди внутрішньої конкуренції не як особистої загрози, а як необхідної умови для реалізації їхнього потенціалу та забезпечення командного результату; розуміння учасниками пріоритету цілей команди порівняно з їхніми індивідуальними цілями, вміння жертвувати власними перевагами на користь досягнення спільної мети; орієнтованість учасників команди на системний професійний та особистісний розвиток та підтримку високого творчого потенціалу; здатність створення конкурентноздатного продукту в результаті командної взаємодії; високий рівень згуртованості, який приводить до отримання конкурентноздатного результату.
На думку І.В. Шульженко, забезпечення високої ефективності команди потребує дотримання таких іiі загальних характеристик, як [3, с. 24]: наявність лідера, який $є$ ядром команди; висока якість кінцевих результатів функціонування команди; високий рівень взаєморозуміння та налагодженості співпраці між учасниками команди задля забезпечення додаткового ефекту їхної співпраці; здатність учасників команди навчатися на власних помилках; орієнтованість на задоволення потреб споживача результатів функціонування команди; створення належної системи мотивації учасників команди до результативної діяльності.

У цій же роботі I.В. Шульженко [3, с. 24] зазначається, що ефективність управлінської команди залежить від трьох таких факторів, як:

- потенційна продуктивність як теоретично досяжний ідеальний рівень продуктивності команди, який може бути забезпечений за умови максимально ефективної взаємодії усіх її учасників;

- синергія як забезпечення синергічного ефекту в результаті співпраці учасників команди на основі поділу загальних цінностей та прагнень, наявності взаємодоповнюючих вмінь та навичок; наявність ефекту синергії приводить до того, що командна робота забезпечує більш високі результати порівняно з індивідуальною роботою учасників, що приводить до перевищення сумарних зусиль учасників команди порівняно з їх простою арифметичною сумою;

- загрози як помилки взаємодії команди, які можуть бути результатом конфліктів, недостатньої компетентності іiї учасників, нераціонально сформованої структури команди та унеможливлюють забезпечення синергетичного ефекту.

Аналіз наведених підходів до визначення критеріїв ефективності функціонування команди свідчить, що всі вони у тій або іншій інтерпретації наголошують на необхідності забезпечення ефекту від взаємодії учасників у вигляді командної синергії [1], високого рівня згуртованості задля отримання конкурентноздатного результату [2], додаткового ефекту командної співпраці [3]. Дійсно, саме єдність зусиль учасників бізнеспроцесу з метою досягнення єдиної мети традиційно 
збільшує ефективність їхньої спільної діяльності. Тому, на наш погляд, визначальною ознакою того, що створення команди було виправданим, буде наявність синергетичного ефекту від взаємодії іiї учасників.

Метою статті $\epsilon$ визначення сутності синергетичного ефекту від функціонування управлінської команди та дослідження передумов його забезпечення.

Виклад основного матеріалу. Синергетичний ефект (ефект синергії, синергійний ефект, від грецьк. synergetikos - спільний, узгоджений, діючий) - це сумарний ефект, який полягає у тому, що під час взаємодії двох або більше факторів їхня дія суттєво переважає ефект кожного окремого компонента у вигляді простої їхньої суми. Також синергетичний ефект у роботах науковців визначається як:

- додатковий результат, отриманий внаслідок високоорганізованої взаємодії окремих елементів єдиної системи, що перевищує вигоду від їхньої діяльності як самостійних елементів [4];

- узгодженість функціонування частин, що відображається в поведінці системи як єдиного цілого [5];

- різниця між сумою властивостей системи і сумою властивостей ії компонентів [6];

- вигода, отримана від комбінування двох або більше елементів таким чином, що продуктивність отриманої комбінації вища, ніж сума ії окремих елементів [7];

- додатковий результат, отриманий від тісної злагодженої взаємодії окремих елементів системи [8].

Інтерес до вивчення управлінського синергізму та факторів його забезпечення пояснюється очевидною важливістю отримання додаткового економічного результату, що є передумовою розвитку будь-якого господарюючого суб'єкта [4]. Фактично отримання ефекту синергії може розглядатися як мета управлінської системи, свідчення доцільності поєднання іiі елементів та результативності їхньої взаємодії. Наявність синергетичного ефекту в системі управління $\epsilon$ наслідком набуття системою такої властивості, як емерджентність, яка полягає в тому, що сукупне функціонування взаємозв'язаних елементів системи породжує якісно нові функціональні властивості системи [9]. Емерджентність - це результат виникнення між елементами системи синергетичних взаємозв'язків, які забезпечують збільшення загального ефекту до більших обсягів, ніж сума ефектів окремо взятих елементів системи, що функціонують незалежно [8, с. 336]. Тобто в категоріях системного підходу створення системи управління є виправданим, а іiі функціонування ефективним, якщо:

$$
E>\sum_{i=1}^{n} E_{i},
$$

де $E$ - ефект, отриманий в результаті взаємодії елементів системи управління;

$E_{i}$ - ефект, отриманий від відокремленого функціонування і-го елемента системи управління;

$n$ - кількість елементів системи управління.

Важливо зазначити, що синергетичний ефект, який за замовчуванням розуміється як позитивний наслідок поєднання елементів в єдине ціле (виражається класичною формулою «2 $+2=5$ та більше»), не є безсумнівним результатом функціонування системи.
У разі незадовільного функціонування системи сума $і 1$ властивостей може виявитися меншою від суми властивостей іiі елементів, що матиме негативний синергетичний ефект (формула « $2+2=3$ та менше»). Також можливим є випадок, коли взаємодія елементів системи ніяким чином не впливає на збільшення іiі результативності порівняно $з$ ізольованим функціонуванням елементів (формула «2 $2=4 »)$. Отже, отримання позитивного синергетичного ефекту управлінської системи не є очевидним обов'язковим результатом, для його забезпечення необхідно докладати відповідних зусиль. Джерелом отримання такого ефекту в системах управління господарюючими суб'єктами можуть виявитися такі фактори, як: обмін досвідом та знаннями; сумісне використання налагоджених контактів; об'єднання фінансових ресурсів; комбінація факторів виробництва; економія на розробках та купівлі нових технологій; спільне використання запасів сировини, обладнання, технічної та технологічної бази; максимальне використання інвестиційного потенціалу [4; 10]. Позитивний синергетичний ефект $\left(S_{E}\right)$ може бути визначений через формулу:

$$
S_{E}>E-\sum_{i=1}^{n} E_{i} .
$$

Під управлінською синергією в роботах науковців розуміється зростання ефективності управління компанією в результаті злагодженої командної взаємодії між керівниками різних підрозділів і різних рівнів управління [11]. За характером виникнення та джерелом походження $є$ управлінська синергія [8]:

- структурна - $є$ результатом налагодження та оптимізації інформаційних потоків та взаємозв'язків між управлінськими групами;

- функціональна - виникає внаслідок налагодженої співпраці в колективі, заснованій на спільній професійній діяльності, єдності цілей та інтересів;

- адміністративна - виникає в результаті оптимального розподілу прав та обов'язків у колективі та забезпечується за рахунок застосування адміністративних або розпорядчих методів впливу на персонал.

У контексті дотримання компетентнісного підходу видається доцільним визначення вимоги одночасного забезпечення вищенаведених видів управлінської синергії, яка може бути визначена як компетенційна синергія та розглядатися як комплексний критерій ефективності функціонування управлінської команди (рис. 1). Умовою забезпечення окремих компонентів компетенційної синергії $\epsilon$ формування раціональних організаційної, рольової та комунікативної структур управлінської команди.

Під організаційною структурою команди розуміється модель формального розподілу повноважень між iii членами, що перебувають між собою у стійких взаємостосунках та забезпечують функціонування і розвиток команди як єдиного цілого. Забезпечення адміністративної синергії може розглядатися як наслідок формування раціональної організаційної структури управлінської команди, до складу якої входять управлінці різних рівнів ієрархії (вертикальна адміністративна синергія) та різних функціональних напрямів (горизонтальна адміністративна синергія). Умовою забезпечення адміністративної синергії $є$ визначення 
необхідного та достатнього для ефективного функціонування команди набору формальних прав та обов'язків, у якому виключається як невиконання, так і дублювання управлінських повноважень.

Не менше значення для забезпечення результативності діяльності команди, ніж формальна організаційна структура, має її рольова структура, тобто розподіл між учасниками командних ролей, які визначаються їхніми суб' єктивними та об'єктивними компетенціями. Суб'єктивна складова частина компетенцій учасників команди залежить від їхніх вроджених здібностей та особистісних інтелектуальних і психофізіологічних можливостей. Об'єктивна складова частина компетенцій учасників команди визначається їхніми теоретичними та практичними знаннями, професійним та соціальним досвідом, навичками та кваліфікацією. Функціональна синергія може бути забезпечена у разі, якщо рольова структура управлінської команди передбачає визначення повного переліку соціально-психологічних ролей та професійних функцій, необхідних для реалізації поставлених завдань.

Забезпечення структурної синергії потребує побудови раціональних інформаційних потоків та необхідних взаємозв'язків між управлінськими групами, що $\epsilon$ результатом створення оптимальної комунікативної структури управлінської команди. Під комунікативною структурою розуміється сукупність інформаційних зв'язків між учасниками групи, які формуються на основі іiї організаційної та рольової структур. Відповідна структура має враховувати як формальний розподіл обов'язків у команді (організаційний аспект), так і команду роль кожного їі учасника, визначену з урахуванням його соціально-психологічних характеристик (рольовий аспект) та професійних компетенцій (професійний аспект).

У разі, якщо організаційна, рольова та комунікативна структури $є$ оптимальними з поглядуу їх відповідності завданням управлінської команди, ефективність діяльності членів команди перевищуватиме їхню

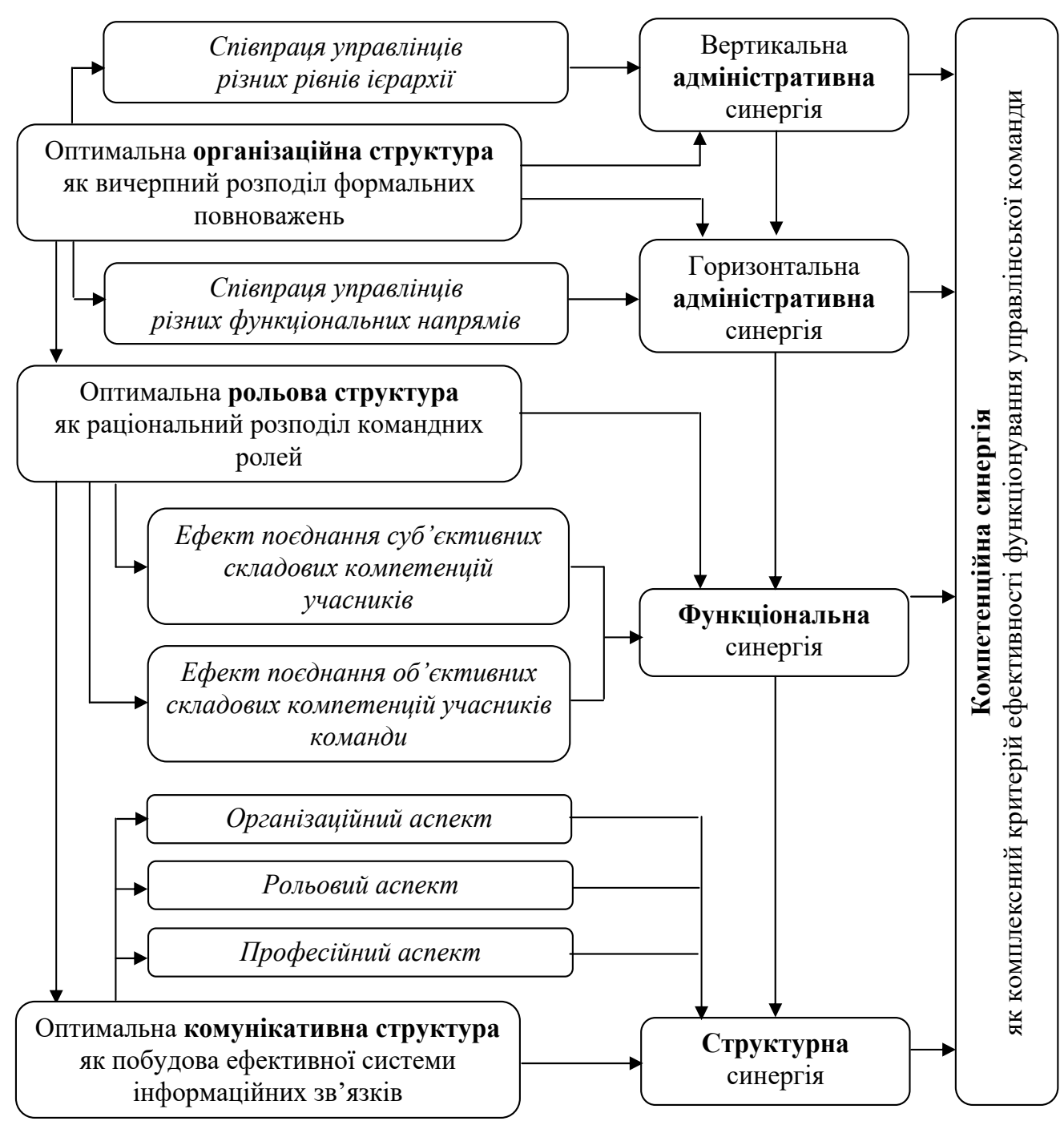

Рисунок 1 - Компетенційна синергія як комплексний критерій ефективності функціонування управлінської команди 
результативність як окремих представників системи управління. Джерелами відповідного синергетичного ефекту виступатимуть:

- оптимізація кількості та структури функціональних обов'язків учасників команди, що забезпечується в результаті співпраці управлінців різних рівнів ієрархії (вертикальна адміністративна синергія) та функціональних напрямів (горизонтальна адміністративна синергія);

- підвищення якості виконання управлінських завдань за рахунок оптимального розподілу соціальнопсихологічних ролей та професійних функцій учасників команди (функціональна синергія);

- підвищення поінформованості учасників команди у процесі виконання поставлених завдань унаслідок побудови ефективної системи інформаційних зв'язків (структурна синергія).

Сумарний синергетичний ефект, який забезпечується у разі формування оптимальних організаційної, рольової та комунікативної структур, можна визначати як компетенційну синергію та розглядати як комплексний критерій ефективності функціонування управлінської команди:

$$
E_{K}=f\left(E_{A}, E_{F}, E_{C}\right) \rightarrow \max ,
$$

де $E_{K}$ - комплексний ефект компетенційної синергії функціонування управлінської команди;
$E_{A}, E_{F}, E_{C}$ - ефекти відповідно адміністративної, функціональної та структурної синергії функціонування управлінської команди.

Висновки. Центральною проблемою оцінювання результативності управлінської команди є забезпечення ії відповідності певним критеріям ефективності функціонування. Аналіз підходів до визначення критеріїв ефективності функціонування команди свідчить, що всі вони у тій або іншій інтерпретації наголошують на необхідності забезпечення синергетичного ефекту від взаємодії іiі учасників. У контексті компетентнісного підходу до управління персоналом джерелом виникнення командної синергії пропонується вважати відповідність організаційної, рольової та комунікативної структур завданням управлінської команди. Відповідний синергетичний ефект може бути визначений як компетенційна синергія та розглядатися як критерій ефективності функціонування управлінської команди. У практичній площині забезпечення комплексного ефекту компетенційної синергії потребує визначення повної множини функціональних обов'язків, командних ролей та інформаційних потоків, необхідних для досягнення цілей управлінської команди, що $є$ перспективою подальших досліджень у сфері управління персоналом на засадах компетентнісного підходу.

\section{Список використаних джерел:}

1. Москаленко В.О. Сучасні підходи до формування команди проекту. Інтелект XXI. 2014. № 5. С. 78-86.

2. Калинець К.С. Сутність та особливості формування управлінської команди. URL: http://me.fem.sumdu.edu.ua/docs/d097. pdf (дата звернення: 02.10.2020).

3. Шульженко І.В., Помаз О.М. Особливості створення ефективної управлінської команди в сучасних умовах. Науковий вісник Полтавського університету економіки і торгівлі. 2016. № 1 (73). С. $23-28$.

4. Бойко Ю.І. Синергетичний ефект як ключовий аспект діяльності об'єднаних територіальних громад. Проблеми теоріi та методології бухгалтерського обліку, контролю і аналізу. 2018. Вип. 1 (39). С. 3-8.

5. Геєць В.М. Національна інноваційна система та інноваційно-інвестиційна діяльність. Економіка Украӥни: стратегія $i$ політика довгострокового розвитку : монографія / за ред. В.М. Гейця. Київ : Ін-т екон. прогнозув. ; Фенікс, 2003. 385 с.

6. Шумпетер Й. Теория экономического развития. Москва : Прогресс, 1982. 278 с.

7. Голік І.Л. Синергетичний ефект діяльності кластерних формувань. Електронний журнал «Ефективна економіка». 2015. № 5. URL: http://www.economy.nayka.com.ua/?op=1\&z=4053 (дата звернення: 02.10.2020).

8. Мельников В.В. Синергетичний ефект при моделюванні інноваційних процесів. Інноваційна економіка. 2014. № 5. C. $335-340$.

9. Економічна кібернетика. Термінологічний словник. URL: https://buklib.net/books/33705/ (дата звернення: 02.10.2020).

10. Ковач М.Й. Синергетичний ефект як важливий фактор інноваційного розвитку економіки. Науковий вісник Ужгородського університету. Серія Економіка. 2017. Вип. 1 (49). Т. 2. С. 84-89.

11. Keating M. The New Regionalism in Western Europe. Territorial Restructuring and Political Change. Cheltenham : Edward Elgar Publishers, 1998. 242 p.

1. Moskalenko V.O. (2014) Suchasni pidkhody do formuvannia komandy proektu [Modern approaches to project team formation]. Intelligence XXI, no. 5, pp. 78-86.

2. Kalynets K.S. Sutnist ta osoblyvosti formuvannia upravlinskoi komandy [The essence and features of the formation of the management team]. Available at: http://me.fem.sumdu.edu.ua/docs/d097.pdf (accessed 2 October 2020).

3. Shulzhenko I.V., Pomaz O.M. (2016) Osoblyvosti stvorennia efektyvnoi upravlinskoi komandy v suchasnykh umovakh [Features of creating an effective management team in modern conditions]. Scientific Bulletin of Poltava University of Economics and Trade, no. 1 (73), pp. 23-28.

4. Boiko Yu.I. (2018) Synerhetychnyi efekt yak kliuchovyi aspekt diialnosti obiednanykh terytorialnykh hromad [Synergetic effect as a key aspect of the activities of united territorial communities]. Problems of theory and methodology of accounting, control and analysis, vol. 1 (39), pp. 3-8.

5. Heiets V.M. (2003) Natsionalna innovatsiina systema ta innovatsiino-investytsiina diialnist [National innovation system and innovation and investment activities]. Ekonomika Ukrainy: stratehiia i polityka dovhostrokovoho rozvytku [Economy of Ukraine: strategy and policy of long-term development]. Kiev: In-t ekon. prohnozuv.; Feniks, 2003.

6. Shumpeter Y. (1982) Teoryia ekonomycheskoho razvytyia [Theory of economic development]. Moskva: Prohress. (in Russian)

7. Holik I.L. (2015) Synerhetychnyi efekt diialnosti klasternykh formuvan [Synergetic effect of cluster formations]. Efficient economy (electronic journal), no. 5. Available at: http://www.economy.nayka.com.ua/?op=1\&z=4053 (accessed 2 October 2020).

8. Melnykov V.V. (2014) Synerhetychnyi efekt pry modeliuvanni innovatsiinykh protsesiv [Synergetic effect in modeling innovation processes]. Innovative economy, no. 5, pp. 335-340. 
9. Ekonomichna kibernetyka. Terminolohichnyi slovnyk [Economic Cybernetics. Terminological dictionary]. Available at: https://buklib.net/books/33705/ (accessed 2 October 2020).

10. Kovach M.I. (2017) Synerhetychnyi efekt yak vazhlyvyi faktor innovatsiinoho rozvytku ekonomiky [Synergetic effect as an important factor of innovative economic development]. Scientific Bulletin of Uzhhorod University. Economics series, vol. 1 (49). T. 2, pp. 84-89.

11. Keating M. (1998) The New Regionalism in Western Europe. Territorial Restructuring and Political Change. Cheltenham: Edward Elgar Publishers.

Korolov Denis

Volodymyr Dahl East Ukrainian National University

\section{COMPETENCE SYNERGY AS EFFICIENCY CRITERIA OF MANAGEMENT TEAMS FUNCTIONING}

The article is devoted to the study of the essence and definition of the prerequisites for ensuring a synergistic effect from the functioning of the management team. The urgency of this issue is due to the decisive role of the team approach in ensuring the competitiveness of management structures in the post-industrial economy. Since the key to building effective management teams is to adhere to the competency approach, it is necessary to justify the positive effect of the diversity and level of development of competencies of team members. In order to solve the set tasks the methods of analysis and synthesis, abstraction and generalization, graphic modeling are used in the article. The article substantiates that the central problem of evaluating the effectiveness of the management team is to ensure its compliance with certain criteria of operational efficiency. Based on the analysis of approaches to determining the criteria of management team effectiveness, the need to ensure a positive effect from the interaction of its members in the form of management synergy, which is defined as increasing the effectiveness of company management as a result of coordinated team interaction between managers and different levels of management. According to the results of the analysis of approaches to the interpretation of managerial synergy, such types as structural (as a result of establishing information flows in the team), functional (as a result of establishing cooperation in the team) and administrative (as a result of optimal distribution of rights and responsibilities). It is shown that the sources of synergetic effect will be the formation of optimal in terms of compliance with the tasks of the team structures: organizational (model of formal division of powers within the team), role (distribution between team members based on their objective and subjective competencies) and communicative (set of information links between team members). The total synergetic effect is defined as a competency synergy and the expediency of its identification with complex efficiency criteria of the management team is substantiated.

Key words: competence approach, management team, structure, efficiency criteria, synergetic effect, competence synergy.

JEL classification: M12, M52, M54 